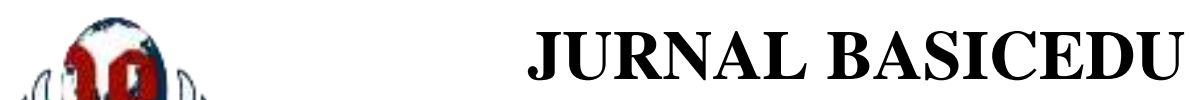

Volume 5 Nomor 6 Tahun 2021 Halaman 6040 - 6048

Research \& Learning in Elementary Education

https://jbasic.org/index.php/basicedu

\title{
Pengembangan Media Pembelajaran Berbasis Website pada Muatan Pembelajaran Matematika Kelas IV
}

\author{
Nugroho Adi Suryandaru ${ }^{1 凶}$, Eunice Widyanti Setyaningtyas ${ }^{2}$ \\ Universitas Kristen Satya Wacana, Indonesia ${ }^{1,2}$ \\ E-mail:292017060@ @student.uksw.edu ${ }^{1}$, Eunice.widyanti@uksw.edu ${ }^{2}$
}

\begin{abstract}
Abstrak
Pada masa pandemi, membuat kegiatan belajar mengajar terhambat dan menuntut guru untuk melakukan pembelajaran dalam jaringan. Penelitian ini bertujuan untuk mengetahui kelayakan media pembelajaran berbasis website pada muatan pembelajaran matematika kelas IV. Jenis penelitian yang digunakan adalah penelitian dan pengembangan yang menggunakan tiga tahap yaitu studi pendahuluan, pengembangan produk, dan pengujian. Teknik analisis data bersifat deskriptif kategori. Teknik tes yang digunakan adalah tes soal evaluasi dalam bentuk pilihan ganda sedangkan teknik nontes yang digunakan observasi. Hasil validasi dari 3 validator yaitu ahli materi, ahli media, dan ahli bahasa, mendapatkan hasil secaara urut $81 \%, 82 \%$, dan $70 \%$, sehingga termasuk dalam kategori tinggi dan dapat digunakan. Hasil uji validitas dan uji reliabilitas soal yaitu dari 15 butir soal didapatkan 1 butir soal memiliki tingkat validasi sangat tinggi yaitu $6,7 \%$, 5 butir soal memiliki tingkat validasi tinggi yaitu 33,3\%, 7 butir soal memiliki tingkat validasi rendah yaitu 46,7\%, dan 2 butir soal memiliki tingkat validasi sangat rendah yaitu $13,3 \%$. Data reliabilias soal yaitu dengan $\alpha$ sebesar 0.825 dengan kriteria sangat reliabel untuk digunakan karena $\alpha>0.8$. Berdasarkan hasil penlitian media pembelajaran berbasis website layak digunakan.
\end{abstract}

Kata Kunci: Pembelajaran Berbasis Website, Matematika Bangun Datar.

\begin{abstract}
During the pandemic, teaching and learning activities are hampered and require teachers to do online learning. This study aims to determine the feasibility of website-based learning media on the content of class IV mathematics learning. The type of research used is research and development that uses three stages, namely preliminary studies, product development, and testing. The data analysis technique is descriptive category. The test technique used is an evaluation test in the form of multiple choice while the non-test technique used is observation. The validation results from 3 validators, namely material experts, media experts, and linguists, obtained results in order of $81 \%, 82 \%$, and $70 \%$, so they were included in the high category and could be used. The results of the validity test and the reliability test of the 15 items found 1 item had a very high validation level of 6.7\%, 5 items had a high validation level of 33.3\%, 7 items had a low validation level of 46, 7\%, and 2 items have a very low validation level of $13.3 \%$. The reliability data of the question is with of 0.825 with very reliable criteria to be used because > 0.8. Based on the results of research, website-based learning media are feasible to use.
\end{abstract}

Keywords: Website-Based Learning, Mathematics geometry 2 dimensions.

Copyright (c) 2021 Nugroho Adi Suryandaru, Eunice Widyanti Setyaningtyas

Corresponding author :

Email:292017060@student.uksw.edu

DOI : https://doi.org/10.31004/basicedu.v5i6.1803

ISSN 2580-3735 (Media Cetak)

ISSN 2580-1147 (Media Online)

Jurnal Basicedu Vol 5 No 6 Tahun 2021

p-ISSN 2580-3735 e-ISSN 2580-1147 
6041 Pengembangan Media Pembelajaran Berbasis Website pada Muatan Pembelajaran Matematika Kelas IV - Nugroho Adi Suryandaru, Eunice Widyanti Setyaningtyas

DOI: https://doi.org/10.31004/basicedu.v5i6.1803

\section{PENDAHULUAN}

Abad ke 21 perkembangan teknologi memberikan dampak hampir di seluruh kehidupan manusia, salah satunya yaitu pada dunia pendidikan (Ghufron 2018). Pendidikan berperan penting untuk meningkatkan kualitas SDM. Pendidikan memiliki fungsi sebagai fasilitas dan sarana dalam memudahkan manusia dalam membimbing maupun mengembangkan kemampuannya, agar dapat bersaing di era globalisasi. Terdapat bermacam perubahan di aspek pendidikan yang dilakukan untuk memberikan peningkatan pada kualitas atau kuantitas pendidikan (Kadi and Awwaliyah 2017). Dalam meningkatkan kualitas pendidikan perlu melakukan beberapa pintasan baik itu dalam mengembankan inovasi pendidikan, pemenuhan sarana dan prasarana serta dalam mengembangkan kurikulum di sekolah. Guru dituntut untuk memberikan pembelajaran yang menarik dan memiliki fungsi serta tujuan yang dapat memotivasi peserta didik (Suprihatin 2015) contohnya seperti mengembangkan media pembelajaran agar dapat meningkatkan proses pembelajaran yang baik.

Pembelajaran merupakan kegiatan yang dilakukan guru dan peserta didik dalam menyampaikan ilmu pengetahuan dan membentuk cara berpikir yang kreatif kepada peserta didik(Annuuru, Johan, and Ali 2017). Pembelajaran yang interaktif tidak lagi berpusat pada pendidik (Teacher Center) melainkan ke segala arah (Salay 2019) Seorang pendidik diharuskan dapat membuat pembelajaran yang mengghasilkan peserta didik yang kreatif (Sani 2013). Penyusunan kegiatan pembelajaran, tentu menggunakan komponen-komponen pembelajaran seperti metode, model, strategi, media pembelajaran, materi, dan evaluasi pembelajaran. Seluruh komponen harus ada disetiap pembelajaran agar tercapainya tujuan pembelajaran

Media pembelajaran merupakan perantara yang digunakan dalam pembelajaran oleh pendidik dalam menyampaikan materi pembelajaran agar menjadi efektif (Tafonao 2018). Peserta didik akan lebih mudah dalam pembelajaran ketika menggunakan media dalam prose pembelajaran (Muhson 2010). Meskipun pendidik menyampaikan pembelajaran dengan gaya mengajar yang berbeda - beda, dan menggunakan media yang berbeda pula, tetapi peserta didik dapat menerima pesan yang sama (Arsyad 2013). Berdasarkan teori kerucut Dale, Media pembelajaran harus mengikuti perkembangan tekhnologi. Perkembangan media selalu mengikuti perkembangan teknologi. Pada masa pandemik di tahun 2019 - 2020 membuat kegiatan belajar mengajar terhambat dan menuntut guru untuk melakukan pembelajaran Daring (Dalam Jaringan). Guru dituntut untuk membuat media pembelajaran yang dapat di gunakan secara online contohnya seperti Video pembelajaran, E-book, Website (Januarisman and Ghufron 2016).

Website adalah sebuah perangkat lunak yang berisi file seperti gambar atau teks yang terhubung dalam sebuah internet. Sumber informasi yang di buat dalam bentuk HTML dan digunakan pengguna web dengan bantuan navigasi ke halaman selanjutnya. (Hartono 2005) mengatakan bahwa halaman-halaman web yang tersimpan dalam sebuah hosting atau web server yang dikunjungi lewat DNS (Domain Name System). Menurut(Juharsa 2012) merupakan suatu format datayang digunakan untuk membuat dokumen hypertext yang dapat dibaca dari suatu platform komputer ke platform komputer lainnya tanpa perlu melakukan suatuperubahan apapun. Dokumen HTML disebut sebagai markup language karenamengandung tanda-tanda tertentu yang digunakan untuk menentukan tampilanteks dan tingkat kepentingan dari text tersebut dalam suatu dokumen. Dengansystem hypertext pada dokumen HTML. Penggunaan HTML memungkinkan pemrogram untuk dengan mudah menghubungkan berbagai jenis dokumen ke satu lokasi. website terdiri dari audio dan visual, konten dari website menentukan jenis dari website itu sendiri seperti wesbite pendidikan dan wesbite perjalanan. wesbite dapat berguna bagi peserta didik di saat pandemi covid-19. Menurut (Scanlon, Buckingham, and Burn 2005) website yang terdiri dari komputer atau laptop dan internet menawarkan potensi untuk mengundang dan memotivasi siswa dalam berbagai metode pembelajaran daripada metode tradisional para pendidik. Dalam beberapa tahun terakhir, website dikenal membuat pembelajaran lebih menyenangkan. Menurut (Rosen and Purinton 2004) yang menyatakan bahwa konten web adalah salah satu faktor yang 
6042 Pengembangan Media Pembelajaran Berbasis Website pada Muatan Pembelajaran Matematika Kelas IV - Nugroho Adi Suryandaru, Eunice Widyanti Setyaningtyas

DOI: https://doi.org/10.31004/basicedu.v5i6.1803

mendukung kunjungan secara berulang, membuat konten yang baik adalah cara yang efektif. Maka dari itu konten dari sebuah website menentukan perhatian peserta didik.

(Supriyono and Sugirin 2014) dalam penelitian yang berjudul "Pengembangan Media Pembelajaran Membaca Bahasa Inggris SMP Berbasis Web" Pembelajaran menggunakan media yang dibuat dapat meningkatkan tingkat ketuntasan belajar siswa sebesar 68\%. Dan juga penelitian yang di lakukan oleh (Budiman, Arifin, and Marlianto 2019), yang berjudul Pengembangan Media Pembelajaran Berbasis ELearning Pada SMK di Pontianak bahwa rancangan dalam pembuatan media pembelajaran e-learning di SMK Pontianak diawali dengan pembuatan storyboard, flowchart, DFD, ERD dan proses terakhir membuat media e-learning menggunakan moodle. Media e-learning mendapatkan nilai rata-rata 85,79\% yang dapat dikatakan sangat layak digunakan, sedangkan respons guru dan siswa terhitung sangat baik karena didapatkan dari angket uji terbatas 78,38\% dengan kategori setuju dan uji lapangat mendapatkan 79,45\% dengan kategori setuju. Berdasarkan penelitian tersebut media pembelajaran yang akan di kembangkan yaitu media pembelajaran berbasis website. Dengan adanya media pembelajaran berbasis web site siswa di harapkan dapat lebih mudah mengakses dan mempelajari materi. Pembelajaran matematika dengan menggunakan website diharapkan dapat memunculkan motivasi belajar peserta didik. Pembelajaran ini menampilkan media yang dapat menarik minat belajar peserta didik, sehingga peserta didik tidak akan merasa bosan dan mudah dalam memahami materi matematika lebih baik.

Penelitian ini bertujuan untuk menghasilkan media pembelajaran berbasis website pada muatan pembelajaran matematika kelas IV SD. Pengembagan media pembelajaran website dapat digunakan guru sebagai media dalam proses kegiatan belajar mengajar. Media pembelajaran ini digunakan untuk memudahkan siswa belajar secara daring serta dapat memberikan manfaat yaitu media pembelajaran ini dibuat semenarik mungkin serta dapat digunakan melalui handphone ataupun personal computer. Hal-hal positif yang ada pada media pembelajaran website untuk siswa dapat memaksimalkan penggunaan smartphone atau komputer untuk kegiatan belajar secara daring. Oleh karena itu untuk mengatasi masalah diatas akan dikembangkan produk media pembelajaran website dengan penelitian yang berjudul "Pengembangan Media Pembelajaran Berbasis Website Pada Muatan Pembelajaran Matematika Kelas IV".

\section{METODE}

Jenis penelitian yang digunakan adalah penelitian pengembangan atau Research and Development $(R \& D)$ dan menggunakan model Borg and Gall. Menurut (Fais, Listyarini, and Tsalatsa 2019) research and development $(R \& D)$ adalah metode penelitian yang digunakan untuk menghasilkan suatu produk tertentu dan menguji keefektifan produk tersebut. Menurut (Sukmadinata Nana 2010a) R\&D merupakan sebuah strategi atau metode penelitian yang cukup ampuh untuk memperbaiki praktik. Menurut (Sukmadinata Nana 2010b) terdapat beberapa langkah penelitian yaitu 1) studi pendahuluan yang meliputi studi literatur, studi lapangan, dan penyusunan draf awal produk. 2) pengembangan, yang terdiri atas uji coba terbatas dan uji coba luas, 3) pengujian. Dalam penelitian ini peneliti menggunakan prosedur penelitian yang diadaptasi dari (Sukmadinata Nana 2010) yang dapat dilihat pada gambar di bawah ini: 
6043 Pengembangan Media Pembelajaran Berbasis Website pada Muatan Pembelajaran Matematika Kelas IV - Nugroho Adi Suryandaru, Eunice Widyanti Setyaningtyas

DOI: https://doi.org/10.31004/basicedu.v5i6.1803

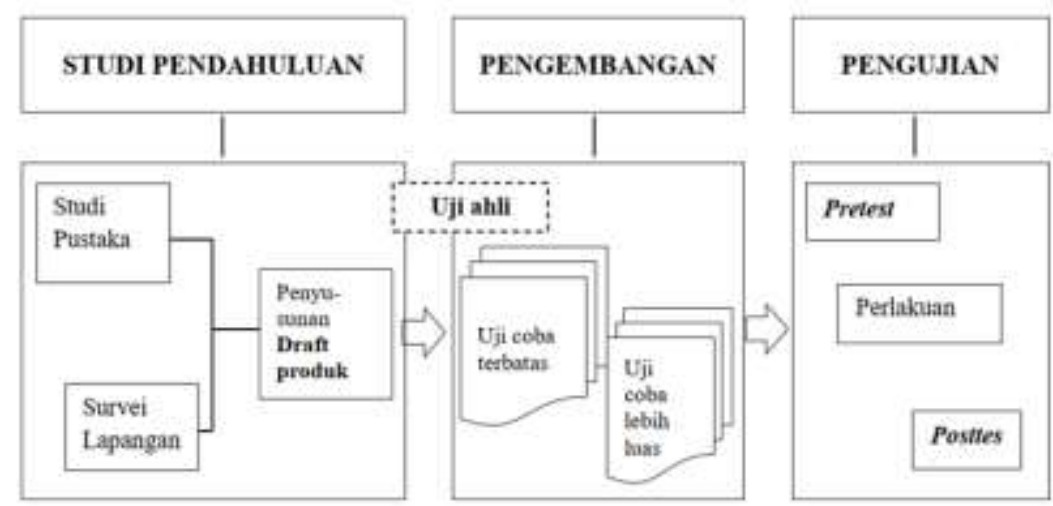

Gambar 1. Tahapam Research and Development

\section{Studi Pendahuluan}

Studi pendahuluan ialah langkah pertama yang dilakukan. Pada studi pendahuluan ini menjelaskan pengembangan media pembelajaran berbasis website pada muatan pembelajaran matematika kelas IV SD.

\section{Studi Pustaka}

Studi pustaka yang diguanakan oleh penliti yaitu melalui jurnal atau artikel, buku, dan penelitian yang relevan.

\section{Survei Lapangan}

Pada tahap ini dilakukan bertujuan untuk memperoleh data dalam perencanaan serta kegiatan belajar mengajar, mengumpulkan informasi pengembangan produk yang akan digunakan untuk mengembangkan media pembelajaran berbasis website pada muatan pembelajaran matematika kelas IV. Sumber yang dikumpulkan untuk pengembangan produk yaitu kompetensi dasar, pengembangan indikator, materi pada muatan pembelajaran, kondisi siswa ketika proses pembelajaran.

\section{Penyusunan Draf Produk Awal}

Penyusunan pada tahap ini yaitu menggunakan hasil studi dan survei lapangan yang telah dilakukan. Peneliti membuat media pembelajaran berbasis website yaitu sebagai berikut :

- Menentukan Kompetensi Dasar

Media pembelajaran berbasis website dibuat sesuai dengan kompetensi dasar kelas iv muatan pembelajaran matematika, materi yang akan digunakan dalam pengembangan ini yaitu bangun datar (KD 3.9 $\& 4.9)$.

- Membuat Rancangan Media Pembelajaran Berbasis Website

Pada tahap merancang media pembelajaran ini, peneliti menentukan rancangan atau template yang akan di isi setiap pilihan menu di website. Rancangan yang akan dibuat terdiri atas: 1) Tata letak layar menu utama, 2) Tata letak menu pembelajaran, 3) Tata letak setiap pembelajaran.

\section{Uji coba terbatas}

Pada tahap ini peneliti akan melakukan validasi dengan cara mengirimkan produk kepada 3 validator yaitu validator pakar materi, pakar media, dan pakar bahasa. Validasi dlakukan untuk mengetahui kelayakan media pembelajaran dengan cara validator mengisi lembar validasi yang sudah dikirimkan oleh peneliti.

Analisis hasil validasi oleh tiga validator (materi, media dan bahasa) terdiri dari teknik deskripsi persentase dan deskripsi kategori dalam menentukan layak atau tidaknya sebuah website. Data validitas media pembelajaran berbasis website dianalisis menggunakan rumus skor yang diperoleh dibagi dengan skor maksimum dikalikan 100\% yang kemudian selanjutnya dikategorikan sesuai kriteria kelayakan. Terdapat lima kriteria penilaian validasi media pembelajaran yaitu kriteria sangat layak apabila persentase mencapai $81 \%$ $100 \%$, kriteria layak apabila persentase mencapai $61 \%-80 \%$, kriteria cukup layak apabila persentase mencapai 
6044 Pengembangan Media Pembelajaran Berbasis Website pada Muatan Pembelajaran Matematika Kelas IV - Nugroho Adi Suryandaru, Eunice Widyanti Setyaningtyas

DOI: https://doi.org/10.31004/basicedu.v5i6.1803

$41 \%-60 \%$, kriteria kurang layak apabila persentase mencapai $21 \%-40 \%$, kriteria tidak layak apabla persentase mencapai <20\%. (Arikunto 2012).

Berdasarkan angket validasi media pembelajaran berbasis website oleh pakar tersebut maka dapat ditarik kesimpulan bahwa media pembelajaran berbasis website dianggap layak apabila skor penilaian aspek yang dinilai $\geq 61 \%$. Apabila skor penilaian aspek yang dinilai $<61 \%$ maka media pembelajaran berbasis website akan direvisi kembali.

\section{Uji coba luas}

Uji coba lua dilaksanakan pada 11 November 2021 di SD Negeri 2 Rojoimo, Kecamatan Wonosobo, Kabupaten Wonosobo, Jawa Tengah. Subjek penelitian ini yaitu siswa kelas IV Sekolah Dasar Negeri 2 Rojoimo dengan jumlah siswa 30.

Penelitian pengembangan ini menghasilkan produk berupa media pembelajaran berbasis website untuk siswa sekolah dasar kelas IV.Instrumen utama dalam penelitian ini adalah peneliti sendiri, sedangkan instrumen pendukung yang digunakan adalah evaluasi soal dengan melakukan uji validitas dan reliabilitas dengan SPSS, semua instrumen yang digunakan telah dinyatakan valid oleh validator.

Teknik pengambilan data dari penelitian ini berupa tes \& wawancara.. Dalam penelitian ini terdapat soal evaluasi. Diberikan 15 buah soal pada 30 siswa kelas IV. Setelah menguji media pembelajaran berbasis website, uji penilaian dilakukan untuk melihat hasil setelah pengujian produk media pembelajaran berbasis website.

Analisis data dari penelitian ini menggunakan tekhnik deskriptif kategori. Aplikasi yang digunakan untuk menganalisis data adalah IBM SPSS 24 for windows yang nantinya akan digunakan untuk menganalisis data dari tingkat validitas dan reliabilitasnya.

\section{Pengujian}

Pengujian yang terdiri dari pengenalan produk dan soal evaluasi tidak dapat dilaksanakan karena dampak covid-19 yang hingga saat ini masih ada sehingga sekolah-sekolah masih ditutup. Pengujian dilakukan dengan cara home visit agar tidak menimbulkan keramaian dan tetap mematuhi protokol kesehatan.

\section{HASIL DAN PEMBAHASAN}

Penelitian ini menghasilkan sebuah produk media pembelajaran berbasis website untuk mempermudah siswa dalam belajar.

\section{Hasil Pengembangan Media Pembelajaran Berbasis Website}

Desain pengembangan produk website disusun sesuai dengan tujuan ialah untuk meningkatkan minat belajar siswa. Pengembangan website ini dapat dibuka dengan handphonelpersoonal computer sebagai media pembelajaran.

Website yang didesain di antaranya adalah pada Tampilan Menu Utama (Home), Tampilan Profil Pengembang, Tampilan menu pembelajaran dan tampilan masing-masing pembelajaran Berikut adalah beberapa draf produk yang dihasilkan di media pembelajaran berbasis website untuk tampilan Tampilan Pembuka, dan Tampilan Menu Pembelajaran 
6045 Pengembangan Media Pembelajaran Berbasis Website pada Muatan Pembelajaran Matematika Kelas IV - Nugroho Adi Suryandaru, Eunice Widyanti Setyaningtyas

DOI: https://doi.org/10.31004/basicedu.v5i6.1803
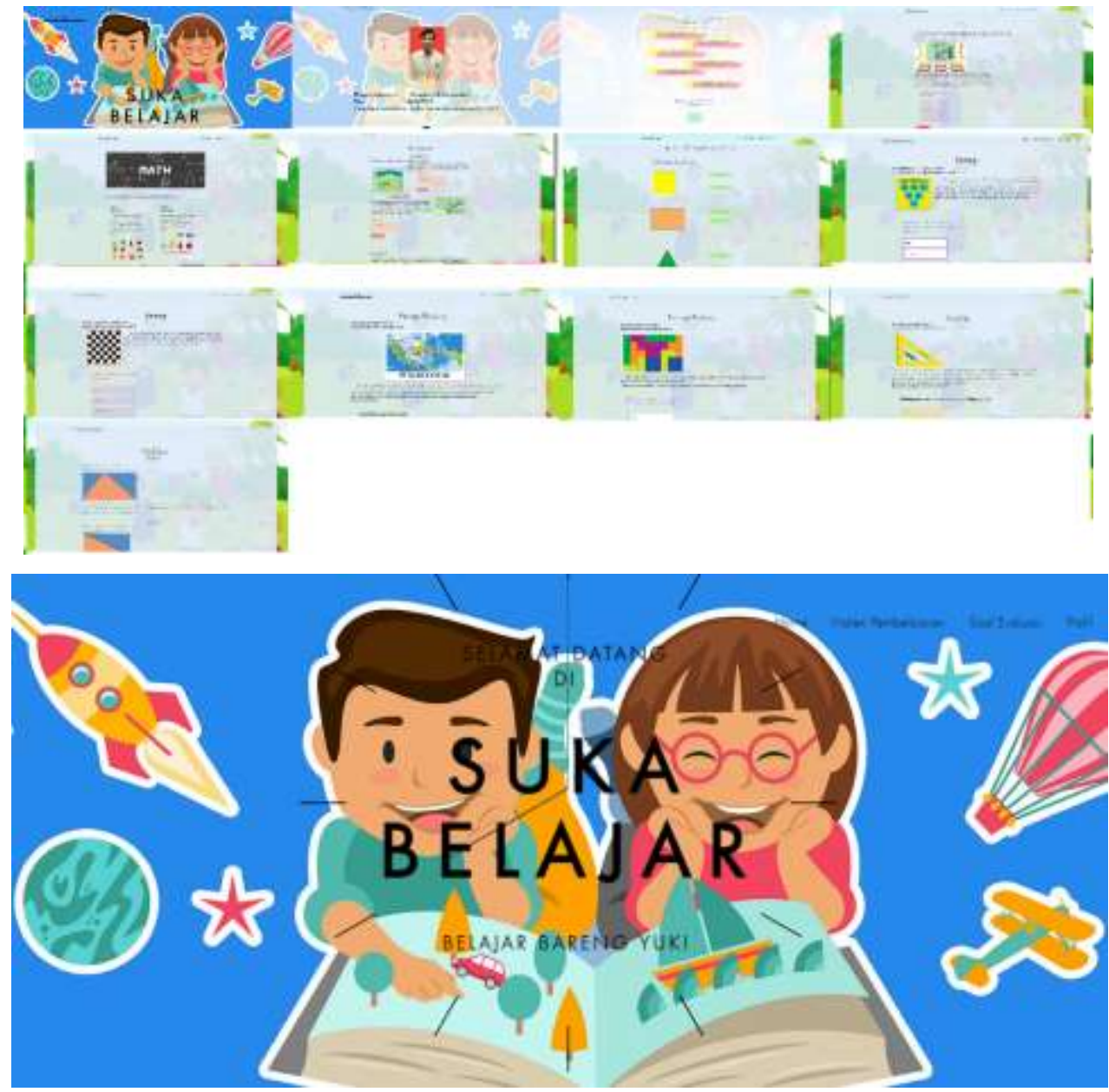

Gambar 2. Tampilan Menu Utama (Home)

Gambar 2. yaitu tampilan utama atau tampilan pembukaan produk website ini terdiri atas judul produk yaitu "SUKA BELAJAR", menu utama, Menu kegiatan perpembelajaran, dan menu profil pengembang. Produk tersebut dapat digunakan oleh siswa secara sederhana dan menarik guna meningkatkan minat belajar.

\section{Hasil Uji Validitas dan Reliabilitas Produk Website}

Sebelum diujikan kepada siswa, website di validasi oleh tim ahli (Pakar) untuk memverifikasi validitasnya. Pembahasan tingkat validitas website dengan skor sebagai berikut:

Tabel 1. Hasil Uji Validitas Pakar

\begin{tabular}{lccccc}
\hline No. & Validator & Skor Ideal & Skor aktual & Angka Persentase & Kategori \\
\hline 1. & Pakat materi & 65 & 53 & $81 \%$ & Sangat layak \\
\hline 2. & Pakar media & 35 & 29 & $82 \%$ & Samgat layak \\
\hline 3. & Pakar bahasa & 40 & 28 & $70 \%$ & Layak \\
\hline
\end{tabular}

Pada ahli materi mendapat skor 53 dari 65 dan persentase $81 \%$ dengan kategori sangat layak. Kemudian, ahli media yang kedua mendapat skor 29 dari 35 dan persentase $82 \%$ dengan kategori sangat layak. Sedangkan dari ahli bahasa mendapat skor 28 dari 40 dengan kategori layak. Berdasarkan tabel hasil uji validasi, produk bisa diuji setelah melakukan revisi sesuai masukan ahli. Berdasarkan tabel kriteria validasi, media pembelajaran berbasis website dapat dianggap layak apabila skor penialaian aspek yang dinilai $\geq 61 \%$ (Arikunto 2012). Validator memberikan saran tentang media pembelajaran berbasis website untuk desain produk yang lebih baik: Sebaiknya materinya disajikan dalam icon icon yang lebih menarik untuk siswa. 
6046 Pengembangan Media Pembelajaran Berbasis Website pada Muatan Pembelajaran Matematika Kelas IV - Nugroho Adi Suryandaru, Eunice Widyanti Setyaningtyas

DOI: https://doi.org/10.31004/basicedu.v5i6.1803

Setelah diberi masukan peneliti melakukan perbaikan agar sesuai dengan masukan kemudian dapat diujikan kepada siswa SD Negeri 2 Rojoimo Wonosobo. Berdasarkan hasil uji validasi yang telah dilakukan, media pembelajar dapat dinyatakan layak dan digunakan setelah melakukan perbaikan. Selanjutnya, uji kevalidan soal evaluasi dari website dianalisis dan diolah menggunakan IBM SPSS 24.

Setelah revisi produk, media pembelajaran berbasis website digunakan untuk uji coba terbatas guna meningkatkan minat belajar siswa kelas IV Sekolah Dasar. Uji coba terbatas dilaksanakan di SD Negeri 2 Rojoimo, Kecamatan Wonosobo, Kabupaten Wonosobo. Uji coba terbatas dengan menggunakan media pembelajaran berbasis website pada kelas IV dengan jumlah siswa atau jumlah sampel sebanyak 30 peserta didik untuk mengerjakan 15 butir soal. Pada tahap penelitian uji terbatas ini akan mengamati minat belajar siswa menggunakan media pembelajaran berbasis website "SUKA BELAJAR" Kelas IV tentang bangun datar. Pada saat uji coba, siswa diberikan produk website. Selanjutnya, siswa mengerjakan soal evaluasi untuk melihat hasil siswa setelah menggunakan produk. Saat pembelajaran menggunakan media pembelajaran berbasis website siswa memberikan respons aktif dan semangat, saat siswa diberikan pertanyaan tentang bangun datar, siswa mampu menjawab secara baik dan benar mengenai bangun datar.

Uji coba lapangan terbatas media pembelajaran berbasis website dilakukan melalui 1 kali uji coba produk dan 1 kali uji soal kepada siswa kelas IV di SD Negeri 2 Rojoimo Wonosobo. Diberikan 15 butir soal kepada 30 peserta didik kelas IV. Soal akan diujikan tingkat validitas dan reliabilitasnya. Koefisien validitas soal dapat dilihat menggunakan program IBM SPSS 24 for windows jika nilai Xtot $\geq 0,361$ maka dinyatakan valid. Data hasil pengolahan IBM SPSS 24 setelah dilakukan uji coba produk media pembelajaran berbasis website, peserta didik diberikan soal yang sama untuk dikerjakan dan diuji lagi kevalidannya. Berdasarkan hasil validitas soal evaluasi dari 15 soal didapatkan 1 butir soal memiliki tingkat validasi sangat tinggi yaitu $6,7 \%, 5$ butir soal memiliki tingkat validasi tinggi yaitu 33,3\%, 7 butir soal memiliki tingkat validasi rendah yaitu $46,7 \%$, dan 2 butir soal memiliki tingkat validasi sangat rendah yaitu 13,3\%. Hasil uji soal tertinggi mendapatkan $\mathrm{r}_{\text {hitung }} 0.835$ berada di antara 0.81-1.00 dengan kategori tinggi dan terendah mendapatkan $\mathrm{r}_{\text {hitung }}$ 0.040 berada di antara 0.00-0.21 dengan kategori sanngat rendah. Berdasarkan tabel distribusi validasi soal pada uji coba lapangan mendapatkan hasil 13 soal valid dan 2 soal tidak valid dari jumlah soal 15 butir.

(Utami and Wardani 2020) menyaatakan bahwa Reliabilitas (ajeg) Tes adalah kemampuan alat ukur untuk memberikan hasil pengukuran yang konstan atau ajeg. Adapun rentang indeks reliabilitas yang terdapat dalam buku (Utami and Wardani 2020). Terdapat lima kategori yaitu kategori sangat tinggi apabila indeks mencapai 0,81-1,00, kategori tinggi apabila indeks mencapai 0,61-0,80, kategori cukup apabila indeks mencapai $0,41-0,60$, kategori rendah apabila indeks mencapai $0,21-0,40$, kategori sangat rendah apabila indeks mencapai 0,00-0,20.

Perhitungan validitas dapat menggunakan rumus korelasi person product moment atau untuk mempermudah, nilai korelasi pearson product moment dapat diperoleh melalui IBM SPSS 24. Apabila nilai dari Corrected Item-Total Correlation $\geq 0,20$ maka dinyatakan valid

Menurut (Utami and Wardani 2020) reliabilitas (ajeg) tes adalah kemampuan alat ukur untuk memberikan hasil pengukuran yang konstan atau ajeg. Rentang indeks reliabilitas dibagi menjadi lima kategori yaitu sangat reliabel dengan indeks $0,81-1,00$, reliabel dengan indeks $0,61-0,80$, cukup reliabel dengan indeks 0,41-0,60, kurang reliabel dengan indeks 0,21-0,40, tidak reliable dengan indeks $<0,20$.

Hasil uji reliabilitas soal pilihan ganda dapat menggunakan metode Alpha-Cronbach yaitu Analyze, Scale, Reliability, klik Alpha, Statistic, Centang menu Item, Scale, scale if item deleted, continue dan klik ok. Jika nilai $\alpha \geq 0,361$ dinyatakan reliabel. Nilai Cronbach's-Alpha sebesar 0,825. Dari data tersebut dapat disimpulkan bahwa data tersebut realiabel. Hasil uji reliabilitas soal pada uji coba terbatas disajikan melalui tabel berikut ini. 
6047 Pengembangan Media Pembelajaran Berbasis Website pada Muatan Pembelajaran Matematika Kelas IV - Nugroho Adi Suryandaru, Eunice Widyanti Setyaningtyas

DOI: https://doi.org/10.31004/basicedu.v5i6.1803

Tabel 2. Hasil Uji Reliabilitas Instrumen Uji coba Produk Akhir Lapangan Lebih Luas

Interpretasi Reliabilitas
Nilai Cronbach's Alpha

$\alpha \geq 361$
0,825

Berdasarkan tabel distribusi reliabilitas, tingkat reliabilitas instrumen sebesar $\alpha$ 0,825 dengan kriteria sangat reliabel karena $\alpha>0,8$.

Hasil penelitian tersebut dapat dilihat media pembelajaran berbasis website layak untuk digunakan sebagai media pembelajaran dalam pembelajaran. Kelayakan produk ini ditunjukkan dengan hasil validasi oleh tiga validator yaitu materi, media, dan bahasa dengan hasil persentase $81 \%$ untuk materi, $82 \%$ untuk media dan $70 \%$ untuk bahasa, sehingga dikategorikan sagatlayak untuk digunakan. Ketika belajar mengajar siswa memberikan respons positif dan saat siswa diberi soal tentang bangun datar, siswa dapat menjawab dengan baik dan benar. Produk ini dapat meningkatkan minat belajar peserta didik di SD Negeri 2 Rojoimo Wonosobo karena dari data validitas dan reliabilitas soal evaluai tinggi. Data reliabilitas pada soal evaluasi yaitu tingkat reliabilitas instrumen sebesar $\alpha 0,825$ dengan kriteria sangat reliabel karena $\alpha>0,8$. Sehingga produk media pembelajaran berbasis website dapat meningkatkan minat belajar siswa yang dibuktikan dengan adanya hasil tes soal evaluasi yang valid dan reliable.

Keunggulan media pembelajaran website adalah dapat diakses kapan saja, di mana saja, mudah digunakan, dan meningkatkan minat belajar siswa karena desain yang dapat menarik perhatian siswa. Materi dari website ini dapat meningkatkan semangat siswa untuk belajar karena multimedia yang dikembangkan dengan materi tersebut dapat menarik perhatian siswa terhadap mata pelajaran.

Implikasi penelitian ini adalah produk media pembelajaran berbasis website dapat digunakan guru kegiatan belajar mengajar secara daring kelas IV. Produk website "SUKA BELAJAR" Kelas IV tentang bangun datar ini dikembangkan sesuai dengan perkembangan usia siswa sehingga siswa dapat antusias ketika belajar dan media pemebelajaran ini diharapkan dapat digunakan seterusnya. Pengembangan produk meliputi menentukan kompetensi dasar (KD), tujuan pembelajaran, indikator pembelajaran, metode pembelajaran, sistematika materi pembelajaran yang disesuaikan dengan kurikulum 2013, dan pengembangan prototipe media pembelajaran yang dirancang. Manfaat media pembelajaran ini ialahh membantu siswa memanfaatkan handphone secaa maksimal dalam kegiatan belajar serta mudah digunakan setiap saat.

\section{KESIMPULAN}

Berdasarkan data hasil penelitian pengembangan media pembelajaran berbasis website yang telah dilakukan, dapat disimpulkan bahwa media pembelajaran ini layak digunakan untuk guru dalam mendukung kegiatan belajar mengajar agar dapat memajukan kualitas pendidikan serta dapat meningkatkan kreativitas guru dalam melakukan kegiatan belajar mengajar. Berdasarkan pengamatan pada saat pengenalan media pembelajaran website, terlihat peserta didik cukup antusias ketika mengikuti pengenalan media pembelajaran berbasis website. Kelebihan dari website dalam pembelajaran adalah dapat mendorong peserta didik untuk lebih aktif dan mandiri dalam belajar, memungkinkan peserta didik belajar dimanapun dan kapanpun, isi dari materi yang tidak membosankan karena mempunyai tampilan yang menarik. Akan tetapi, ada beberapa kekurangan dari website sebagai pembelajaran yaitu membutuhkan smarthphone / komputer dan akses internet untuk mengakses website yang dimana tidak semua peserta didik memiliki, keberhasilan pembelajaran tergantung dari motivasi dan kemandirian peserta didik, kurangnya interaksi antara guru dan peserta didik secara langsung. 
6048 Pengembangan Media Pembelajaran Berbasis Website pada Muatan Pembelajaran Matematika Kelas IV - Nugroho Adi Suryandaru, Eunice Widyanti Setyaningtyas

DOI: https://doi.org/10.31004/basicedu.v5i6.1803

\section{DAFTAR PUSTAKA}

Annuuru, Tia Agusti, Riche Cynthia Johan, And Mohammad Ali. 2017. "Peningkatan Kemampuan Berpikir Tingkat Tinggi Dalam Pelajaran Ilmu Pengetahuan Alam Peserta Didik Sekolah Dasar Melalui Model Pembelajaran Treffinger." Educational Technologia 1(2).

Arikunto, S. 2012. Prosedur Penelitian Suatu Pendekatan Praktik. Jakarta: Rineka Cipta.

Arsyad, Azhar. 2013. "Media Pembelajaran; Edisi Revisi."

Budiman, Aris, Ardian Arifin, And Ferry Marlianto. 2019. "Pengembangan Media Pembelajaran Berbasis ELearning Pada Smk Di Pontianak." Jurnal Nasional Komputasi Dan Teknologi Informasi (Jnkti) 2(2):133-39.

Fais, Muhammad Zaenal, Ikha Listyarini, And Ahmad Nashir Tsalatsa. 2019. "Pengembangan Media Papin Dan Koja (Papan Pintar Dan Kotak Ajaib) Sebagai Media Pembelajaran Matematika." Jurnal Penelitian Dan Pengembangan Pendidikan 3(1):26-30.

Ghufron, Ghufron. 2018. "Revolusi Industri 4.0: Tantangan, Peluang, Dan Solusi Bagi Dunia Pendidikan.” In Seminar Nasional Dan Diskusi Panel Multidisiplin Hasil Penelitian Dan Pengabdian Kepada Masyarakat 2018. Vol. 1.

Hartono, Jogiyanto. 2005. “Analisis Dan Desain Sistem Informasi: Pendekatan Terstruktur Teori Dan Praktek Aplikasi Bisnis." Yogyakarta: Andi.

Januarisman, Erwin, And Anik Ghufron. 2016. "Pengembangan Media Pembelajaran Berbasis Web Mata Pelajaran Ilmu Pengetahuan Alam Untuk Siswa Kelas Vii." Jurnal Inovasi Teknologi Pendidikan 3(2):166-82.

Juharsa, Jujun. 2012. "Materi I."

Kadi, Titi, And Robiatul Awwaliyah. 2017. "Inovasi Pendidikan: Upaya Penyelesaian Problematika Pendidikan Di Indonesia.” Jurnal Islam Nusantara 1(2).

Muhson, Ali. 2010. "Pengembangan Media Pembelajaran Berbasis Teknologi Informasi." Jurnal Pendidikan Akuntansi Indonesia 8(2).

Rosen, Deborah E., And Elizabeth Purinton. 2004. "Website Design: Viewing The Web As A Cognitive Landscape.” Journal Of Business Research 57(7):787-94.

Salay, Rahila. 2019. "Perbedaan Motivasi Belajar Siswa Yang Mendapatkan Teacher Centered Learning (Tcl) Dengan Student Centered Learning (Scl)."

Sani, Ridwan Abdullah. 2013. "Inovasi Pembelajaran.” Jakarta: Bumi Aksara.

Scanlon, Margaret, David Buckingham, And Andrew Burn. 2005. "Motivating Maths? Digital Games And Mathematical Learning." Technology, Pedagogy And Education 14(1):127-39.

Sukmadinata Nana, Syaodih. 2010. "Metode Penelitian Pendidikan.” Bandung: Remaja Rosdakarya.

Suprihatin, Siti. 2015. "Upaya Guru Dalam Meningkatkan Motivasi Belajar Siswa." Jurnal Pendidikan Ekonomi Um Metro 3(1):73-82.

Supriyono, Kandung, And Sugirin Sugirin. 2014. "Pengembangan Media Pembelajaran Membaca Bahasa Inggris Smp Berbasis Web.” Jurnal Inovasi Teknologi Pendidikan 1(1):49-64.

Tafonao, Talizaro. 2018. "Peranan Media Pembelajaran Dalam Meningkatkan Minat Belajar Mahasiswa." Jurnal Komunikasi Pendidikan 2(2):103-14.

Utami, Diah Ayu Putri, And Naniek Sulistya Wardani. 2020. "Pengembangan Instrumen Penilaian Kognitif Dalam Pembelajaran Tematik Kelas 5 Sd.” Jurnal Ilmiah Kependidikan 13(1):1-18. 